\title{
INVESTIGATION OF PHYSICAL ACTIVITY AND SPORTS CONSUMPTION HABITS IN UNIVERSITY STUDENTS
}

\section{BADANIE AKTYWNOŚCI FIZYCZNEJ I NAWYKÓW KONSUMPCJI SPORTOWEJ WŚRóD STUDENTÓW}

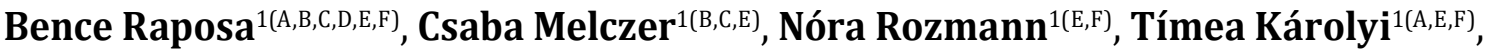 \\ Gyula Takacs $^{1(\mathrm{~A}, \mathrm{E}, \mathrm{G})}$, Valentina Doma ${ }^{1(\mathrm{~B}, \mathrm{D}, \mathrm{F})}$, Viktória Prémusz ${ }^{1(\mathrm{~A}, \mathrm{E}, \mathrm{F}, \mathrm{G})}$, Márton Pintér ${ }^{1(\mathrm{~A}, \mathrm{~B}, \mathrm{D})}$, \\ John Macharia ${ }^{1(A, C, D)}$, Pongrác Ács ${ }^{1(B, C, D, G)}$
}

${ }^{1}$ Faculty of Health Sciences, University of Pécs, Hungary

Authors' contribution Wkład autorów: A. Study design/planning zaplanowanie badań B. Data collection/entry zebranie danych C. Data analysis/statistics dane - analiza i statystyki D. Data interpretation interpretacja danych E. Preparation of manuscript przygotowanie artykułu F. Literature analysis/search wyszukiwanie i analiza literatury G. Funds collection zebranie funduszy

Tables: 2

Figures: 5

References: 30

Submitted: 2020 Jun 30

Accepted: 2020 Jul 27

\section{Summary}

Background. Adequate level of physical activity helps and provides optimal body function. Understanding the sports consumption and physical activity indicators of young adults helps to develop strategies that can help to understand the economic and health background of endemic diseases.

Material and methods. We conducted cross-sectional research at the University of Pécs, Hungary, in 2018. We used an anonymous, self-edited, self-administered online questionnaire. The questions related to demographics, physical activity, sport and health motivation, and lifestyle. Our aim was to characterize the physical activity and sports consumption habits of the students.

Results. In terms of health status and quality of life, the whole sample $(n=197)$ marked theirs as better than average. In the case of sports motivation, we hypothesized that there would be a significant difference between gender; apart from fitness status $(p=0.64)$, we found significantly different motivation levels in each case. In terms of physical activity, women were more engaged in housework and transport, whilst men were more active in free time and work. Conclusions. Our sample's health status and quality of life is adequate. Men's physical activity exceeds women, however, when comparing activity-related MET (metabolic equivalent of task) between the sexes, we did not find significant differences in any case $(p \geq 0.05)$.

Keywords: students, physical activity, IPAQ, sports consumption, MET

\section{Streszczenie}

Wprowadzenie. Odpowiedni poziom aktywności fizycznej wspomaga i zapewnia optymalne funkcjonowanie organizmu. Zrozumienie wskaźników konsumpcji sportowej oraz aktywności fizycznej wśród młodych dorosłych pomaga opracować strategie, które mogą pomóc określić ekonomiczne i zdrowotne źródła chorób endemicznych.

Materiał i metody. W 2018 roku przeprowadziliśmy badania przekrojowe na Uniwersytecie w Peczu (Węgry). Wykorzystaliśmy anonimowy, samodzielnie zredagowany i wypełniany kwestionariusz internetowy. Pytania dotyczyły demografii, aktywności fizycznej, motywacji dotyczącej sportu i zdrowia oraz stylu życia. Naszym celem było scharakteryzowanie aktywności fizycznej i nawyków konsumpcji sportowej studentów.

Wyniki. Pod względem stanu zdrowia i jakości życia wszyscy respondenci $(n=197)$ ocenili swój stan powyżej środkowej wartości skali. W przypadku motywacji dotyczącej sportu postawiliśmy hipotezę, że istnieje znacząca różnica między płciami w zakresie czynników motywacyjnych. W każdym przypadku poza wskaźnikiem stanu sprawności $(p=0,64)$ stwierdziliśmy istotnie odmienne poziomy motywacji. Kobiety wykazały większą aktywność fizyczną w pracach domowych i transporcie, a mężczyźni - w czasie wolnym oraz podczas pracy.

Wnioski. Stan zdrowia respondentów i ich jakość życia są właściwe. Aktywność fizyczna mężczyzn przewyższa aktywność fizyczną kobiet. Podczas porównywania ekwiwalentu metabolicznego (MET) związanego z aktywnością obu płci nie stwierdziliśmy jednak istotnej różnicy w żadnym przypadku ( $\mathrm{p} \geq 0,05)$.

Słowa kluczowe: studenci, aktywność fizyczna, IPAQ, konsumpcja sportowa, MET

Raposa B, Melczer C, Rozmann N, Károlyi T, Takacs G, Doma V, et al. Investigation of physical activity and sports consumption habits in university students. Health Prob Civil. 2020; 14(3): 211-220. https://doi.org/10.5114/hpc.2020.97897

Address for correspondence / Adres korespondencyjny: Bence Raposa, Faculty of Health Sciences, University of Pécs, Vörösmarty Mihály str. 4, 7621 Pécs, Hungary, e-mail: raposa.bence@gmail.com, phone: +36 72513670

ORCID: Bence Raposa https://orcid.org/0000-0001-9551-8440; Csaba Melczer https://orcid.org/0000-0002-8197-0572;

Viktória Prémusz https://orcid.org/0000-0002-4059-104X; Pongrác Ács https://orcid.org/0000-0002-4999-7345

Copyright: ( C Pope John Paul II State School of Higher Education in Biała Podlaska, Bence Raposa, Csaba Melczer, Nóra Rozmann, Tímea Károlyi, Gyula Takacs, Valentina Doma, Viktória Prémusz, Márton Pintér, John Macharia, Pongrác Ács. This is an Open Access journal, all articles are distributed under the terms of the Creative Commons Attribution-NonCommercial-ShareAlike 4.0 International (CC BY-NC-SA 4.0) License (http://creativecommons.org/licenses/by-nc-sa/4.0/), allowing third parties to copy and redistribute the material in any medium or format and to remix, transform, and build upon the material, provided the original work is properly cited and states its license. 


\section{Introduction}

The many positive effects of physical activity are well known; adequate physical activity helps build and maintain healthy bone and muscle tone, maintains optimal metabolism, reduces stress levels and promotes well-being, and forms the basis for a healthy lifestyle [1,2].

This study aims to investigate, from a sociological and leisure use perspective, sports activities, i.e., the frequency and duration of active or passive leisure time in the lifestyle of the population, as well as the factors that influence the use of time. From an economic perspective, it seeks to elucidate sports-related expenditures in the household budget [3].

Several significant studies have been conducted in Hungary on this topic, the results of which served as a good starting point and basis for this study. Szabó examined leisure and sports consumption habits, as well as sports choices, among university students and young adults [4]. In her doctoral dissertation, Neuilinger also dealt with the choice of sports, as well as the factors influencing sports habits, their frequency, and passive sports consumption [5]. Perényi also examined these sociodemographic factors and their effects on the willingness to participate in sports [6]. Földesiné et al. in their research, besides the topics above, focused on social attitudes, especially the attitudes of different sports [7]. Sports consumption was investigated, from an economic point of view, by Ács et al. [8] and Paár [9]. Ács et al. analyzed the burdens of physical inactivity on the national economy, as well as the positive consequences and contributions of the reduction of inactivity [8]. Paár focused on the population's sports consumption, especially the sports expenses of the population, its structure and extent [9].

The research conducted by Antal Kovács and his colleagues also focused on the sports consumption habits of households. Their aim was to explore the sociodemographic and economic factors influencing sports expenses, the desire to participate in sports, and the pursuit of sports activities itself, and to compare them with the existing published literature. They paid special attention to quantifying all these factors in more detail for the households than in prior studies.

It was found that a higher proportion of men than women are athletes, and the level of education determines the propensity to play sports, as it has been shown that a higher proportion of athletes are present among those with a high level of education [10].

Ács et al. in the article "Changes in indicators, related to sports and physical activity in Hungary and the European Union following the results of recent years", examined the indicators related to sports and physical activity, from the perspective of activity promotion strategy creators in the European Union and Hungary. In their analysis, they used representative data from the international Eurobarometer survey $(2010,2014,2018)$. Due to the standardized methodology, the changes of the examined period could also be described: in the EU, in 2017 the Nordic states were the most active, with Finland (69\%), Sweden (67\%), and Denmark (63\%) exhibiting the highest proportion of regular sporting activity within the population.

Almost half of all EU citizens never exercise, and this proportion has gradually increased in recent years. More than half of European citizens do not engage in strong physical activity on a weekly basis, and around $50 \%$ do not do even partake in moderate physical activity either. Fifteen percent of Europeans never walk for more than 10 minutes per week, while $12 \%$ of them sit at least 8.5 hours per day. There is an improving trend in the Hungarian statistical data: compared to 2009, the number of people partaking in daily sporting activities has almost doubled (increased to 9\%), whilst the physically inactive (never partake in sports, or 1-3 times a month or less) numbers decreased by $10 \%$. However, the results have declined compared to 2013 values. The authors hypothesize that the short-term results of recent sports policy decisions predict significant outcomes [11].

It should be mentioned the result, that - in addition to sports consumption habits - examined the attitudes related to physical activity, influencing the quality of life of Hungarian society. In this study, risk factors were identified that could also determine the country's competitiveness. The study highlights that, according to WHO research, some factors contribute to the health of society in the following percentages: $25 \%$ - inherited traits, $18 \%$ - healthcare service, $37 \%$ - the attitude of the individual towards health, lifestyle, and $20 \%-$ environmental effects. In their research, 1185 adolescents, 679 university students and 718 adults were polled via questionnaire; respondents' health status was marked as "very good" by $27.8 \%$ of adolescents, $16.4 \%$ of the university students, and $8.3 \%$ of the adults. Researchers have pointed to the beneficial effects of sport and physical activity, and its effects on quality of life [12].

Our aim was to characterize the physical activity and sports consumption habits of students of at the University of Pécs, Hungary. The study not only helps to understand the students' sports consumption habits, but can be used much more extensively: in terms of our results, for sports infrastructure managed by the university, and also for development guidelines for sports service portfolio, suggestions can be made that could have marked benefits for the sport of the university in the future. To set up the study aims, we tried to ensure 
that our research results could accurately determine sports consumption habits, physical activity, and in the case of different student groups, clarifying the well-defined needs of the target audience.

\section{Material and methods}

\section{Research design}

We conducted cross-sectional, quantitative research at the Faculty of Health Sciences, University of Pécs, Hungary, with physiotherapy and sports \& recreation management students, from February to March 2018. Students who had no legal relationship with the faculty or who are studying in another specialty were excluded.

\section{Setting and participants}

In our research, we used convenience sampling. We invited participants through the Neptun system (unified online education system) of the Faculty of Health Sciences to answer the questionnaire.

Our questionnaire was completed by 197 students, of whom 108 were physiotherapy students and 89 were sports \& recreation management students. Our total sample size was 197 ( $\mathrm{n}=197)$.

\section{Data collection and instruments}

In our research, we used an anonymous, self-edited, self-administered online questionnaire, it contained own parts and other, standardized question groups. The questions were related to demographics, physical activity, sport and health motivation, and lifestyle. The Self-Rated Health (SRH), and the Health-Related Quality of Life (HRQOL) were determined by the WHO Quality of Life Questionnaire (WHOQoL-BREEF) 1(G1) and 2(G4) questions. These ask, on a 5-level Likert scale, how satisfied the respondent is with his/her health and his/her quality of life $[13,14]$.

To determinate the motivation of sport, we used the Special EUROBAROMETER 472 - "Sport and Physical Activity" questionnaire, the question for motivation (QB8) [15]. Furthermore, the nature and intensity of physical activity was investigated with the IPAQ-L questionnaire, because it has already been shown to be of adequate validity and reliability, in a wide range of adult population studies $[16,17]$. The IPAQ-L questionnaire comprises 27 items, and measures physical activity according to different subscales, such as "work - transport - housework - free time - walking". The results were determined in MET (metabolic equivalent of task) and minutes. The Hungarian version was translated and validated by the committee of the Faculty of Health Sciences, University of Pécs. The tool is valid and reliable for the Hungarian population [18,19].

In our study, the independent variables were the participant's gender, the faculty. The dependent variables were given by the participant's physical activity habits, quality of life, self-assessed health status, sports motivations, and the subscales of IPAQ-L data.

\section{Statistical analysis}

Descriptive and comparative statistical methods were also used in the analysis of the sample. For the analysis, we used SPSS 26.0 and Microsoft Excel 2016. Differences for continuous variables concerning the quality of life, motivation, sports consumption - according to the results of the normality test (Kolmogorov-Smirnov Test) were tested with the non-parametric Mann-Whitney probe, while the categorized variables were examined by Chi-square test.

The level of statistical significance was determined to be $\mathrm{p} \leq 0.05$ with a $95 \%$ confidence interval.

\section{Bioethical permission}

The ethical approval was granted for the study by Ethics Committee of University of Pécs (No. 6955/2017). Participants were informed about the research aim and methods before signing the informed consent form. The investigation conforms to the principles outlined in the Declaration of Helsinki. 


\section{Results}

\section{Socio-demographic results}

In our study, there was a greater number of physiotherapy students ( $n=108 ; 54.8 \%)$ than sport \& recreation management students ( $\mathrm{n}=89 ; 45.2 \%)$, which can be explained by the longer training time, as well as admission statistics of the last 4 years.

In terms of gender, there were 72 men (36.5\%) and 125 women (63.5\%) in the sample. Due to the nature of the training, the sample represents the distribution of gender of the students at the Faculty of Health Sciences. The inclusion of academic years was not evenly distributed in the survey: 89 people (45.2\%) first, 8 people (4.1\%) second, 99 people (50.3\%) third, and only 1 person $(0.5 \%)$ in fourth year responded to our questionnaire. Fourth year students, due to their demanding schedule and second-year students due to an online marketing error, participated in lower numbers.

Respondents lived mainly in cities ( $n=85 ; 43.1 \%)$, but are represented in the capital $(n=21 ; 10.7 \%)$, in countryside $(n=43 ; 21.8 \%)$ and in villages $(n=48 ; 24.4)$ too. In our sample, the respondents were primarily single $(n=162 ; 82.2 \%)$, with smaller numbers in a relationship $(n=22 ; 11.2 \%)$, married $(n=11 ; 5.6 \%)$, or divorced $(n=2$; $1.0 \%)$.

The majority of the students $(\mathrm{n}=164 ; 83.2 \%)$ considered the financial situation of their family to be average, 26 people (13.2\%) above, and 7 people (3.6\%) below.

\section{Health status and quality of life}

The majority of students in the sample (105 people, or 53.3\%) were mostly satisfied, 50 people (25.4\%) at least moderate, 32 people (16.2\%) completely satisfied with their health. The negative judgment was negligible - 1 person $(0.5 \%)$ was unsatisfied, with no respondent not at all satisfied with their health status (Figure 1). Overall, the number of respondents equal to, or above average (moderately satisfied with their health) was $187(n=187)$, representing $94.9 \%$ of the sample. The majority of people $(n=143 ; 72.6 \%)$ were mostly satisfied with their quality of life, 30 people (15.2\%) completely, while 22 people $(11.2 \%)$ moderately satisfied with their quality of life. There were only 2 people (1\%) who were dissatisfied. No student rated their quality of life as "not at all" satisfied (Figure 2). The number of respondents who were equivalent to or above average (moderately satisfied with their quality of life) was 185 ( $n=185)$, equating to $93.9 \%$ of the sample.

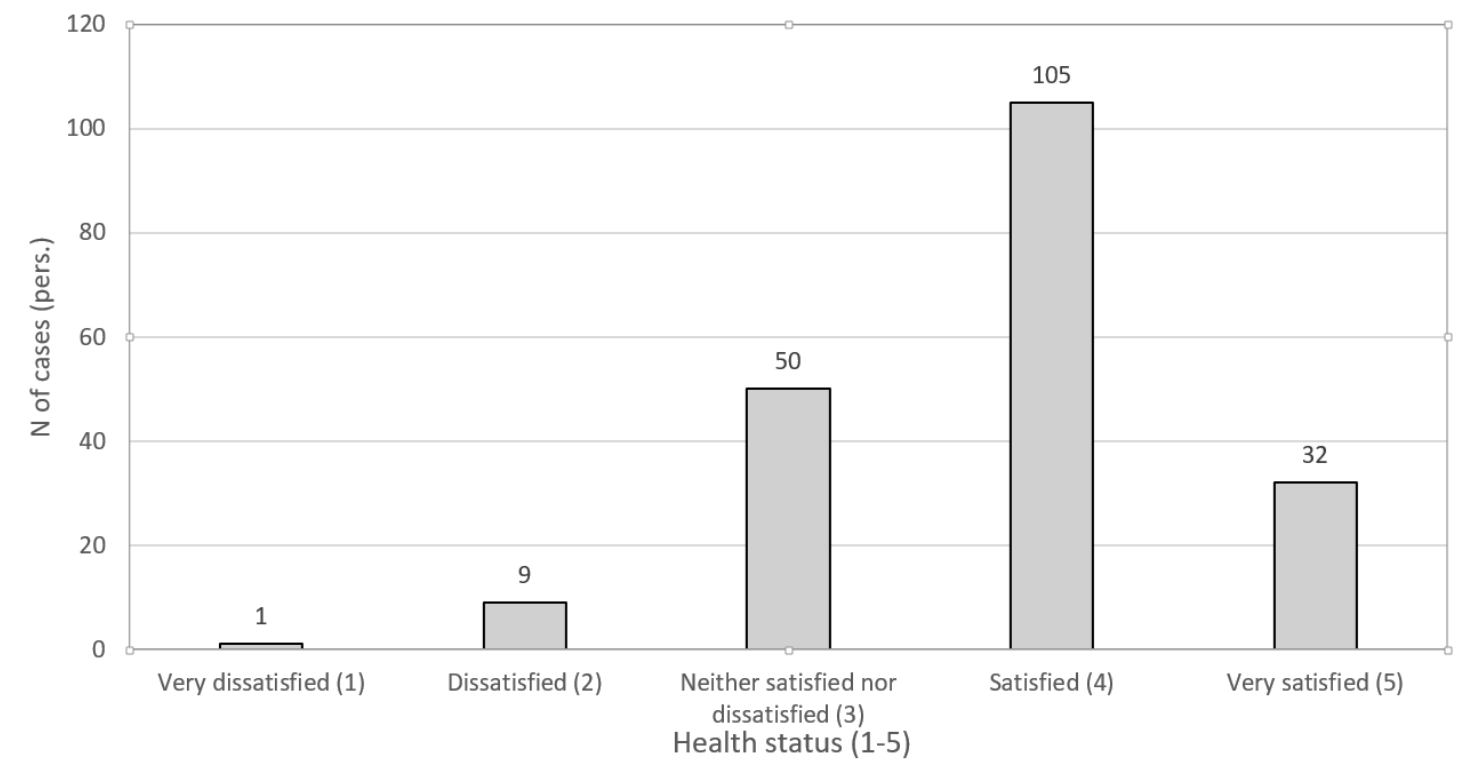

Figure 1. How satisfied are you with your health? (WHOQoL-BREEF - 2(G4))(n=197) 


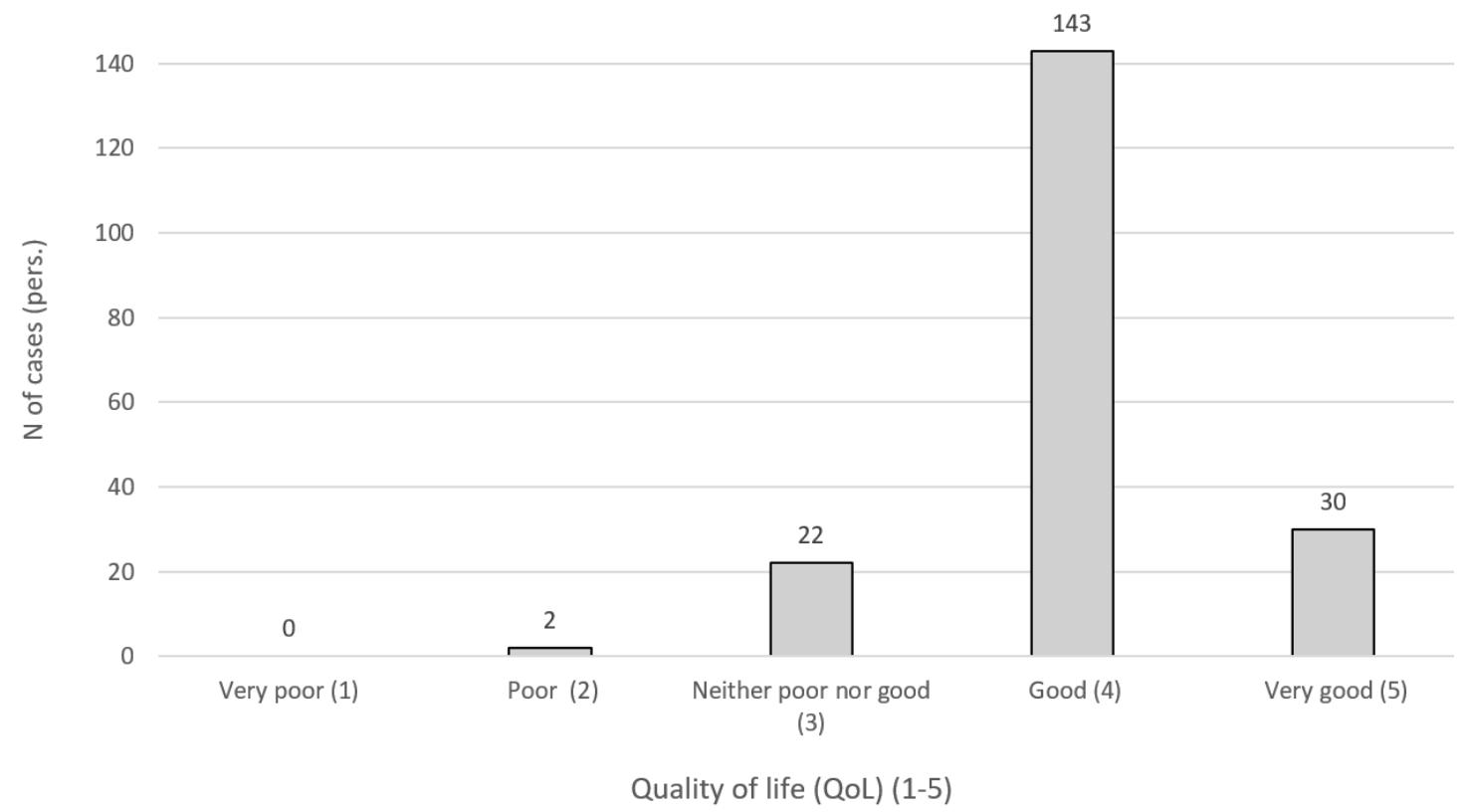

Figure 2. How would you rate your quality of life? (WHOQoL-BREEF - 1(G1) (n=197)

\section{Physical activity and motivations}

The general questions related to the frequency of exercise investigated if respondents were taking part in any physical activity, and if yes, how many times per week. In total 154 people performed regular physical activity (80.39\%), most of them at least 3 times per week. The regular exercise data is presented in Figure 3.

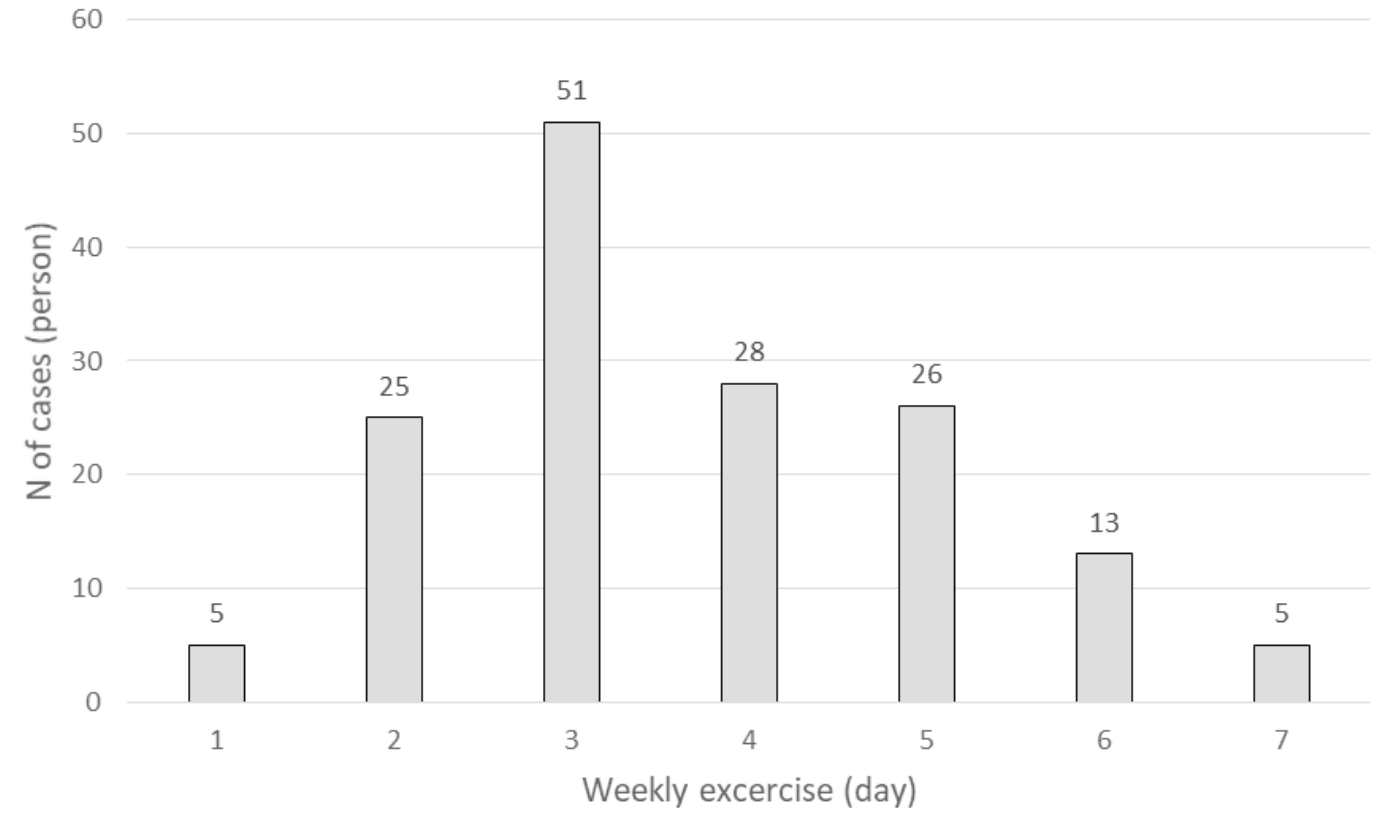

Figure 3. Regular exercise weekly ( $\mathrm{n}=197)$

For the "Why you do sports or do physical exercise?" question (Special EUROBAROMETER 472 - Sport and Physical Activity), regardless of gender, the most common answers were: for relaxation, 41 people (20.8\%); to improve physical appearance, 37 people (18.8\%); to improve his/her health, 34 people (17.3\%). The first three priorities were practically twice as important, among the chosen motivations, for both genders. In terms of gender distribution, there were significant differences in the motivation for sport, with the exception of fitness status (the main motivations presented in Figure 4). 
Aesthetics, self-esteem, relaxation, health and fitness were more characteristic of women, while the competition, friendship, the acquisition of knowledge, and skills development were more motivating for men, in the order of importance listed (Figure 4).

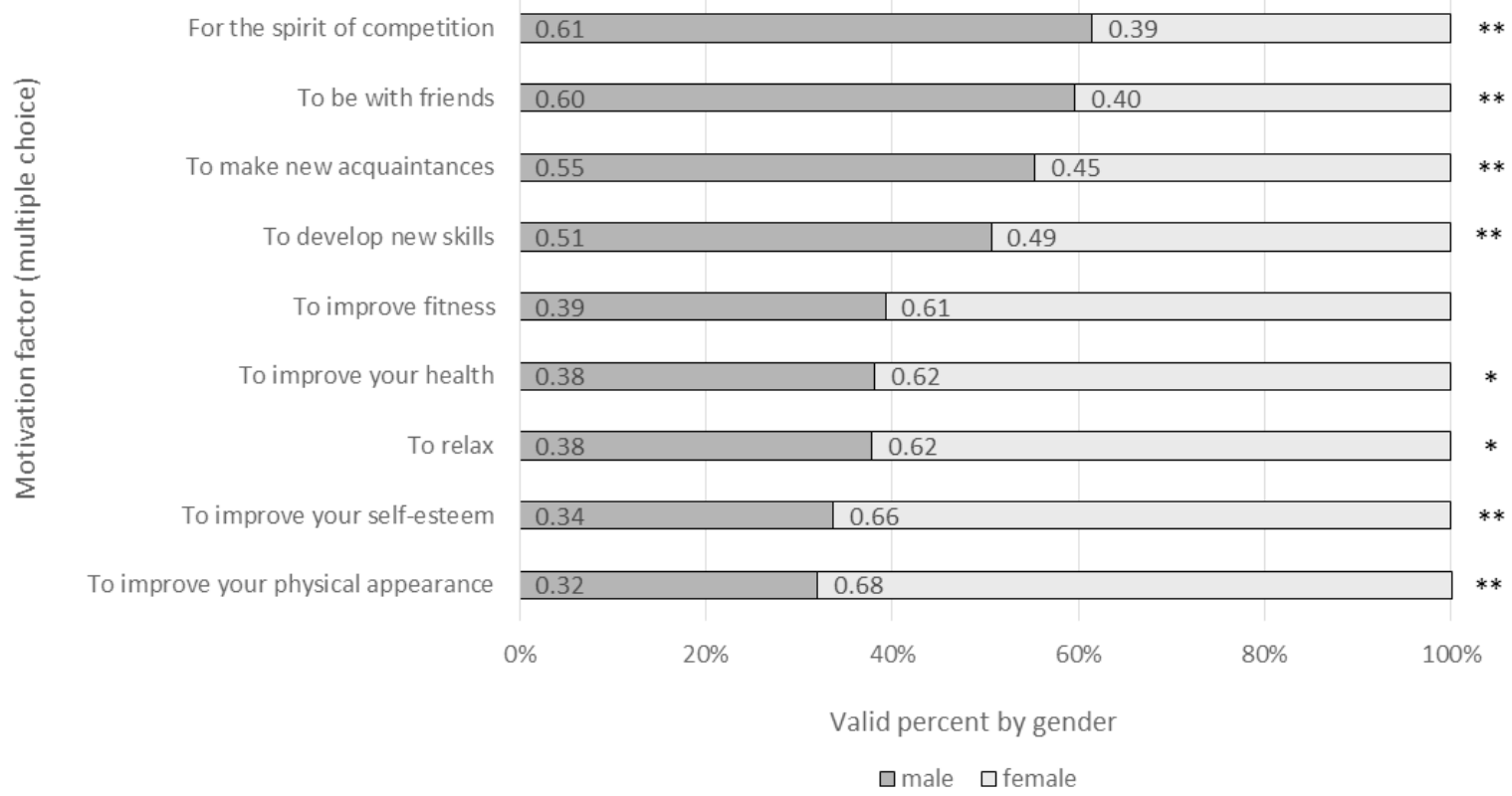

Figure 4. Why do you engage in sport or physical activity? (Special EUROBAROMETER 472 - QB8)

Notes: Asterisks indicate statistical significance $\left({ }^{*} \mathrm{p}<0.05 ;{ }^{* *} \mathrm{p}<0.001\right)$.

Analysis of the duration of physical activity was also performed by gender: $44.8 \%$ of men indicated $61-90$ minutes, and $31.1 \%$ of women marked the 46-60 minutes interval as the time frame for sports per occasion. Using a chi-square test, we found that there was also a significant difference $(\mathrm{p} \leq 0.001)$ between the gender and the time spent partaking in sports (Figure 5).

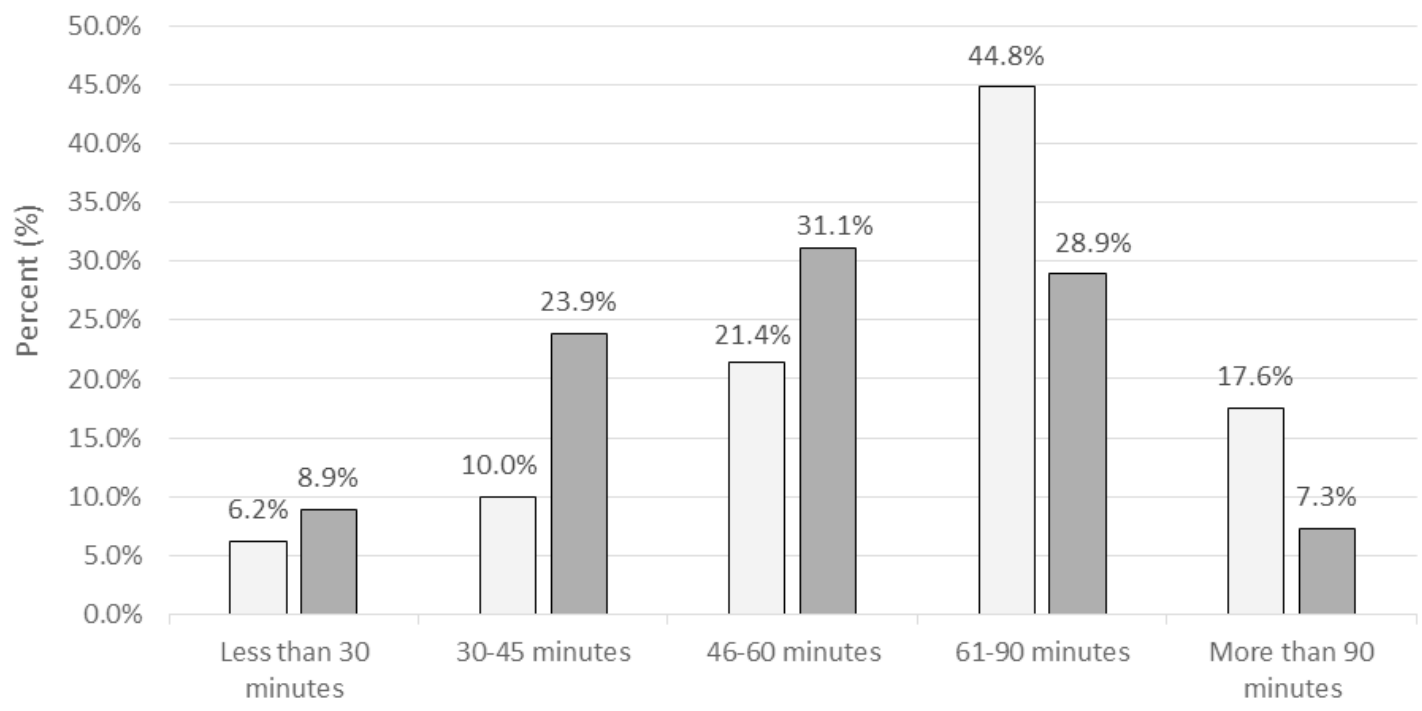

Duration time of physical activity (occassionally)

$\square$ male $\square$ female

Figure 5. University students' duration of physical activity per session (n=197) 
Multidimensional subscales of the IPAQ-L questionnaire were used to determine the intensity of physical activity. During the analysis of the questionnaire's "work - transport - housework - free time - walk" subscale specified variables, when comparing averages, there were appreciable differences between genders.

In terms of physical activity during work, compared to the average 3054.48 MET/week (metabolic equivalent of task per week) (SD \pm 4422.62 ) men had higher (4062.96 MET/week; SD \pm 5847.80$)$, while women exhibited lower (2481.66 MET/week; SD \pm 3246.74 ) values. In case of active transport, we observed opposite results: compared to the population's average (1633.51 MET/week; SD \pm 1965.86$)$, women had slightly higher values (1664.67 MET/ week; SD \pm 2228.83 ), while men’s were slightly lower (1579.41 MET/week; SD \pm 1409.90 ).

Women tended to perform more housework, while men engaged in more free time and walking; however, neither of these differences were found to be statistically significant ( $\mathrm{p} \geq 0.05)$. The responding students' exact MET values and the p-values of their comparison are summarized in Table 1.

Table 1. Analysis of physical activity according to the International Physical Activity Questionnaire-Long (IPAQ-L) subscales 1 (MET)

\begin{tabular}{|c|c|c|c|c|c|c|}
\hline & & $\begin{array}{c}\text { Job-related } \\
\text { physical activity } \\
\text { total MET }\end{array}$ & $\begin{array}{c}\text { Transportation } \\
\text { related physical } \\
\text { activity total } \\
\text { MET }\end{array}$ & $\begin{array}{c}\text { Housework, } \\
\text { house } \\
\text { maintenance, } \\
\text { and caring for } \\
\text { family total MET } \\
\text { (per week) }\end{array}$ & $\begin{array}{c}\text { Recreation, } \\
\text { sport and } \\
\text { leisure-time } \\
\text { physical activity } \\
\text { total MET }\end{array}$ & $\begin{array}{c}\text { Walking MET } \\
\text { Total }\end{array}$ \\
\hline \multirow{3}{*}{ Total } & Mean & 3054.48 & 1633.51 & 761.49 & 2231.60 & 2552.37 \\
\hline & $\mathbf{N}$ & 196 & 197 & 197 & 197 & 197 \\
\hline & SD & 4422.62 & 1965.86 & 1148.62 & 3178.54 & 2432.27 \\
\hline \multirow{3}{*}{ Male } & Mean & 4062.96 & 1579.41 & 750.60 & 2521.77 & 3039.53 \\
\hline & $\mathbf{N}$ & 71 & 72 & 72 & 72 & 72 \\
\hline & SD & 5847.80 & 1409.90 & 1040.89 & 2849.11 & 3337.62 \\
\hline \multirow{3}{*}{ Female } & Mean & 2481.66 & 1664.67 & 767.76 & 2064.46 & 2271.77 \\
\hline & $\mathbf{N}$ & 125 & 125 & 125 & 125 & 125 \\
\hline & SD & 3246.74 & 2228.83 & 1210.34 & 3353.28 & 1659.96 \\
\hline \multicolumn{2}{|c|}{ p-value } & 0.816 & 0.526 & 0.509 & 0.203 & 0.73 \\
\hline
\end{tabular}

Notes: Asterisks indicate statistical significance $\left({ }^{*} \mathrm{p}<0.05\right)$.

Women partake more than men in moderate physical activity (2157.65 vs. 2091.25 MET/week) (p $\geq 0.05)$, while the reverse is true of intense physical activity, with men doing more (3780.56 vs. 2549.12 MET/week), with a statistically significant gender difference being observed in intense physical activity $(p=0.03)$. In the total IPAQ weekly value, the result of men (8953.82 MET/week) was higher than women's (6978.54 MET/week), however this difference was not statistically significant $(\mathrm{p} \geq 0.05)$.

In terms of weekly sit, the difference was significant: for women, the average was 2569.90 minutes/week ( $\mathrm{SD} \pm 969.03)$, while men was 2088.11 minutes/week $(\mathrm{SD} \pm 1062.75)(\mathrm{p}=0.002)$. The average daily sit values mirror the weekly results of the week, with women's higher (367.13 minutes/week; SD \pm 138.43 ) than men's (298.30 minutes/week; $\mathrm{SD} \pm 151.82)$, which was also statistically significant $(\mathrm{p}=0.002)$. The results of physical activity with different intensity, the total MET value and the sitting interval are summarized in Table 2.

Table 2. Analysis of physical activity according to the International Physical Activity Questionnaire-Long (IPAQ-L) subscales 2 (MET)

\begin{tabular}{|c|c|c|c|c|c|c|}
\hline \multicolumn{2}{|c|}{} & $\begin{array}{c}\text { Moderate MET } \\
\text { Total }\end{array}$ & $\begin{array}{c}\text { Vigorous MET } \\
\text { Total }\end{array}$ & $\begin{array}{c}\text { Time spent } \\
\text { seT Total } \\
\text { (per week) }\end{array}$ & $\begin{array}{c}\text { Time spent } \\
\text { sitting } \\
\text { (per week in } \\
\text { minutes) }\end{array}$ & $\begin{array}{c}\text { (daily average in } \\
\text { minutes) }\end{array}$ \\
\hline \multirow{4}{*}{ Total } & Mean & 2133.60 & 2999.19 & 7694.08 & 2393.82 & 341.97 \\
\cline { 2 - 8 } & N & 196 & 197 & 196 & 197 & 197 \\
\hline \multirow{3}{*}{ Male } & Mean & 2613.20 & 4179.25 & 6355.95 & 1028.26 & 146.89 \\
\cline { 2 - 8 } & N & 2091.25 & 3780.56 & 8953.82 & 2088.11 & 298.30 \\
\cline { 2 - 8 } & SD & 71 & 72 & 71 & 72 & 72 \\
\hline
\end{tabular}




\begin{tabular}{|c|c|c|c|c|c|c|}
\hline \multirow{3}{*}{ Female } & Mean & 2157.65 & 2549.12 & 6978.54 & 2569.90 & 367.13 \\
\cline { 2 - 7 } & $\mathbf{N}$ & 125 & 125 & 125 & 125 & 125 \\
\cline { 2 - 7 } & $\mathbf{S D}$ & 2834.48 & 3992.21 & 5786.88 & 969.03 & 138.43 \\
\hline \multicolumn{2}{|c|}{ p-value } & 0.985 & $\mathbf{0 . 0 3 0} *$ & 0.118 & $\mathbf{0 . 0 0 2} *$ & $\mathbf{0 . 0 0 2} *$ \\
\hline
\end{tabular}

Notes: Asterisks indicate statistical significance $\left({ }^{*} \mathrm{p}<0.05\right)$.

\section{Discussion}

Based on published literature, it can be said that the frequency and level of physical activity is decreasing among young adults, which may be leading to a higher risk of obesity and other chronic diseases worldwide [11].

In this study, 78\% of the sample perform regular physical exercise, i.e., partakes in sport at least three times per week, meaning these students reach the desired frequency specified by the WHO Physical Activity Guidelines [20,21].

According to our preliminary assumption, based on self-assessment, our students health status and quality of life would be equivalent or better than the average on a five grade Likert-scale; $94.9 \%$ of the whole sample ( $n=197)$, judged their health status to be better than average. Considering quality of life, 93.9\% were better than the average, so it can be stated that our hypothesis was confirmed.

Most of the students were satisfied with their health condition and quality of life. According to one piece of Hungarian literature, $13.6 \%$ of university students stated their health status as very good; in our sample, we measured $16.2 \%$, so our results are similar to research with larger samples, within university students [22].

No respondent stated that their quality of life was very bad, and on the scale measured data followed the ratio of the health status data, so quality of life positively correlates with health status, in accordance with international literature $[23,24]$.

In the case of sports motivation we hypothesized that there would be significant gender differences between each motivation factor. This hypothesis was also confirmed because, aside from the fitness status ( $p=0.64)$, we found significantly different levels of motivation in each case. The aesthetics, self-evaluation, relaxation, health promotion, and fitness was more typical for women, while the competition, friendship, knowledge acquisition, and skill development was more common in men.

Regardless of gender, the students' priority was relaxation, improving their appearance, and preserving their health, as opposed to self-esteem and weight problems (relaxation: $20.8 \%$, physical appearance: $18.8 \%$, health preservation: 17.3\%). These results partly follow the Special EUROBAROMETER 472 survey's report, because we found similar motivation factors (relaxation, health) in the first three places. It should be mentioned, however, that the order of preference was different; also, instead of physical appearance, fitness improvement was the primary motivator for the adult European and Hungarian populations (health-fitness-relaxation) [15]. Our results show the system of preferences of these groups, and these results can certainly be a guideline in the future, when encouraging them to engage in sports.

Our hypothesis for the time interval of physical activity was also confirmed: $44.8 \%$ of men indicated $61-90$ minutes, and $31.1 \%$ of women marked the $46-60$ minutes interval as the time frame for sports $(p \leq 0.001)$. The result may be partially explained by team sports, which are preferred by men.

Based on IPAQ subscale results, which is used for more detailed and accurate assessments of physical activity: men sit less than women, which confirms the findings of previously published literature [25,26]. Our results also confirm the literature data, that in the case of work and free time, men are more active, which is possibly due to occasional hard and light physical work, as well as sporting activity, among university students $[8,12]$.

In our research, women proved to be more active in transport and housework, although this is a smaller difference than in the case of free time and work. However, this result differs from the overall average measured in the V4 countries (Czech Republic, Poland, Hungary, Slovakia), whereby the men, on average, have been more active in respect of these activities. Based on these results, it can be said that our research reflects Hungarian social conventions and usual gender roles [27-30].

\section{Limitations of the study}

There was a majority of women in our sample, which may be explained by the nature of their coursework.

The distribution by year also shows great heterogeneity. Regarding the low number of fourth year students, it must be noted that during the investigation period, these students were completing their clinical practice, therefore making it difficult to contact them. Fourth year students are more active, and have no obligation to attend classes; had there been greater numbers of these students, our results could possibly have been distorted, 
so we did not set up a hypothesis comparing academic years.

The students' education specialty, marital status and the type of residence was just analyzed with descriptive statistics, as the primary focus was the comparison of physical activity and sports consumption between genders (the variables mentioned above showed significant heterogeneity).

\section{Conclusions}

Overall, it can be said that the health status and quality of life of our sample is adequate. The physical activity of men exceeds that of women in several cases, however in comparison activity-related MET between the sexes, we did not find significant differences in any case $(\mathrm{p} \geq 0.05)$.

Consequently, we can state that during the formulation of directives for institution development, it is reasonable to consider the gender differences relating the nature of the physical activity, sports consumption behavior, and motivation. Rethinking the institution's sports strategy, it is essential to adjust to the existing infrastructure and to the information revealed by this research. New sport directives to be established could only be integrated into a department that operates a centralized sports infrastructure, where the claims get into a so-called “single gate system”. The „single-gate system” means just one, centered department which provides the highest level of knowledge and care about University sport services. Ensuring that the university sports services cater to the broadest audience possible not only promotes building the community, but reduces the direct and indirect effects of cardiorespiratory, cardiovascular, and metabolic symptoms associated with lower activity, and grants the long-term health promotion of our students.

\section{Disclosures and acknowledgements}

The publication costs were partially funded by the Human Resource Development Operational Programme, grant no.: HRDOP-3.6.2-16-2017-00003, Cooperative Research Network in Economy of Sport, Recreation and Health. The authors declare that the study design, collection, management, analysis, and interpretation of data, and writing of the manuscript were independent of Human Resource Development Operational Programme.

\section{References:}

1. Chobanian AV, Bakris GL, Black HR, Cushman WC, Green LA, Izzo JL, et al. Seventh report of the Joint National Committee on Prevention, Detection, Evaluation, and Treatment of High Blood Presure. Journal of the American Medical Association. 2004; 289(19): 2660-2571.

2. Wareham N, Van Sluijs E, Ekelund U. Physical activity and obesity prevention: a review of the current evidence. Proceedings of the Nutrition Society. 2005; 64(2): 229-247. https://doi.org/10.1079/PNS2005423

3. Csóka L, Törőcsik M. [Sport consumption and scales measuring the sport motivation]. Marketing \& Menedzsment. 2019; 53(Special Issue): 77-86 (in Hungarian).

https://doi.org/10.15170/MM.2019.53.EMOK.08

4. Szabó Á. [Consumption of leisure sports (services) by university students. No. 76 Study Workshop]. Budapest: Corvinus University; 2006 (in Hungarian).

5. Neulinger Á. [Social environment and sports consumption. Learned consumption that requires constant reinforcement]. [dissertation]. Budapest: Corvinus University; 2007 (in Hungarian).

6. Perényi S. [Relationships between sports activity and value orientation in young persons]. Új Ifjúsági Szemle. 2008; 6: 71-84 (in Hungarian).

7. Földesiné SG, Gál A, Dóczi T. [Social report on sports]. Budapest: ÖM Sport Szakállamtitkárság - Magyar Sporttudományi Társaság; 2008 (in Hungarian).

8. Ács P, Hécz RM, Paár D, Stocker M. [The value of fitness - the burden of physical inactivity on the national economy in Hungary]. Közgazdasági Szemle. 2011; 58(7-8): 689-708 (in Hungarian).

9. Paár D. [Economic analysis of the sports consumption in Hungarian households]. [dissertation]. Sopron: Nyugat-magyarországi Egyetem; 2013 (in Hungarian).

10. Kovács A, Paár D, Welker Z, Fürész D, Elbert G, Stocker M, et al. [Actual situation of sports consumption habits]. Magyar Sporttudományi Szemle. 2016; 17(68): 17-22 (in Hungarian).

11. Ács P, Prémusz V, Morvay-Sey K, Kovács A, Makai A, Elbert G. [Changes in indicators related to sports and physical activity in Hungary and the European Union following the results of recent years]. Sport- és Egészségtudományi füzetek. 2018; 2(1): 65-80 (in Hungarian).

12. Ács P, Borsos A, Rétsági E. [A quick report on the attitudes of Hungarian society towards physical activity that affects the quality of life]. Magyar Sporttudományi füzetek. 2011; 1: 66-70 (in Hungarian). 
13. WHOQOL Group. Development of the WHOQOL: rationale and current status. Int J Mental Health. 1994; 23 : 24-56. https://doi.org/10.1080/00207411.1994.11449286

14. WHOQOL Group. The World Health Organization Quality of Life assessment (WHOQOL): Position paper from the World Health Organization. Soc Sci Med. 1995; 41: 1403-1409. https://doi.org/10.1016/0277-9536(95)00112-K

15. European Opinion Research Group. Special Eurobarometer 472 - Sport and physical activity report [Internet]. Brussels: European Commission; 2018 [cited 2020 Jun 20]. Available from: http://eose.org/wpcontent/uploads/2018/03/ebs_472_en.pdf

16. Harrison CL, Thompson RG, Teede HJ, Lombard CB. Measuring physical activity during pregnancy. Int J Behav Nutr Phys Act. 2011; 8: article number 19. https://doi.org/10.1186/1479-5868-8-19

17. Craig C, Marshall AL, Sjostrom M, Bauman AE, Booth ML, Ainsowrth BE, et al. International Physical Activity Questionnaire: 12-country reliability and validity. Med Sci Sports Exerc. 2003; 35(8): $1381-1395$. https://doi.org/10.1249/01.MSS.0000078924.61453.FB

18. www.ipaq.ki.se [Internet]. International Physical Activity Questionnaire [cited 2020 Jun 20]. Available from: http://www.ipaq.ki.se/scoring.htm

19. Ács P, Betlehem J, Oláh A, Bergier J, Melczer C, Prémusz V, et al. Measurement of public health benefits of physical activity: validity and reliability study of the International Physical Activity Questionnaire in Hungary. BMC Public Health. Forthcoming 2020.

20. World Health Organization. Global recommendation on physical activity for health [Internet]. Geneva: World Health Organization; 2010 [cited 2020 Jun 20]. Available from: https://apps.who.int/iris/bitstream/ handle/10665/44399/9789241599979_eng.pdf?sequence=1

21. Fagaras SP, Radu LE, Vanvu G. The level of physical activity of university students. Procedia - Social and Behavioral Sciences. 2015; 197: 1454-1457. https://doi.org/10.1016/j.sbspro.2015.07.094

22. Balajti IV. [The health status and the health behaviour of university students]. Debrecen: University of Debrecen; 2010 (in Hungarian).

23. Grembowski D, Patrick D, Diehr P, Durham M, Beresford S, Kay E, et al. Self-efficacy and health behavior among older adults. J Health Soc Behav. 1993; 34(2): 89-104. https://doi.org/10.2307/2137237

24. Axelsson L, Andersson IH, Edén L, Ejlertsson G. Inequalities of quality of life in unemployed young adults: a population-based questionnaire study. Int J Equity Health. 2007; 6: 1. https://doi.org/10.1186/1475-9276-6-1

25. Bauman A, Ainsworth BE, Sallis JF, Hagströmer M, Craig CL, Bull FC, et al. The descriptive epidemiology of sitting. A 20-country comparison using the International Physical Activity Questionnaire (IPAQ). Am J Prev Med. 2011; 41(2): 228-235. https://doi.org/10.1016/j.amepre.2011.05.003

26. Dagmar S, Erik S, Karel F, Aleš S. Gender differences in physical activity, sedentary behavior and BMI in the Liberec Region: the IPAQ Study in 2002-2009. J Hum Kinet. 2011; 28:123-131. https://doi.org/10.2478/v10078-011-0029-6

27. Bergier B, Tsos A, Bergier J. Factors determining physical activity of Ukrainian students. Ann Agric Environ. Med. 2014; 21(3): 613-616. https://doi.org/10.5604/12321966.1120612

28. Bergier B, Bergier J, Paprzycki P. Level and determinants of physical activity among school adolescents in Poland. Ann Agric Environ Med. 2014; 21(1): 75-78. https://doi.org/10.5604/12321966.1120612

29. Junger J, Frömel K, Bergier J, Ács P, Bergier B, Salonna F, et al. Physical activity in students from the Visegrad countries by BMI status. Health Prob Civil. 2018; 12(1): 41-48. https://doi.org/10.5114/hpc.2018.74191

30. Tsos A, Bergier B, Bergier J. Physical activity, physical development and eating habits within the lifestyle of students from Ukraine. Health Prob Civil. 2014; 8(4): 46-53. https://doi.org/10.5114/hpc.2014.57092 